Dept. of Animal Hygiene,

Fac. of Vet. Med., Assiut University.

\title{
EFFECT OF HOTLY SUMMER IN ASSIUT ON HEALTH STATUS, PRODUCTIVITY AND BEHAVIOR OF FRIESIAN DAIRY CATTLE AND THE EVALUATION OF TRADITIONAL
}

By

\author{
S.A. KOTB; MADEHA H.A. DARWISH* \\ and M.A. ABDEL-RAHMAN* \\ *Dept. of Animal Behavior and Management. \\ Fac. of Vet. Med., Assiut University.
}

(Received at 2/10/2007)
تأثير الصيف الحار فى اسيوط على صحة وانتاج وسلوكيات أبقار الفريزيان

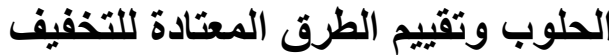

صابر عبل المتجلي قطب , ملبحة حنس /حمد , معتز /حد عبل الرحمن تم إجر اء هذه الدراسة فى مزرعة للأبقار الحلوب داخل محافظة أسيوط خلال الفترة من يوليو الإني

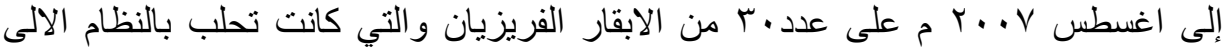

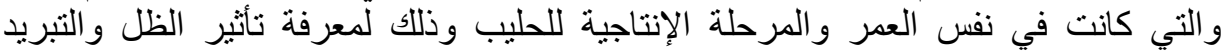

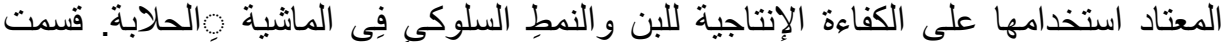

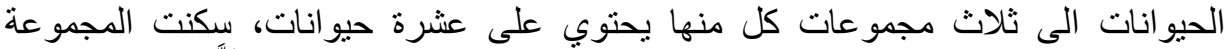

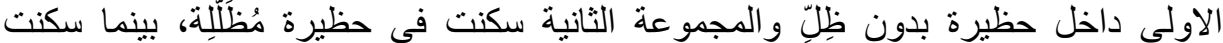

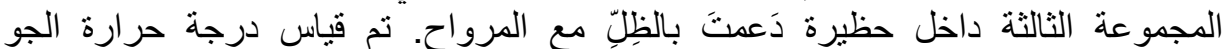

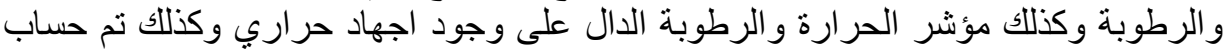

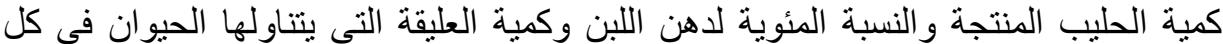

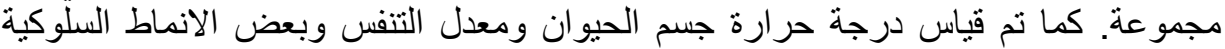

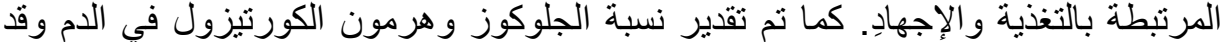

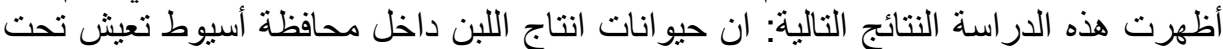

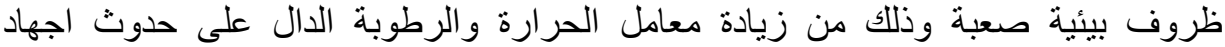

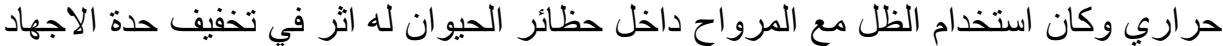

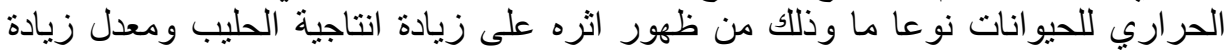

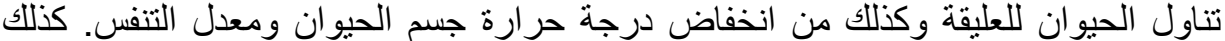

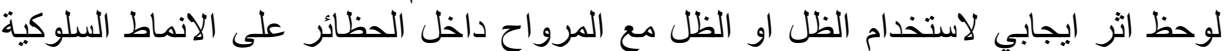

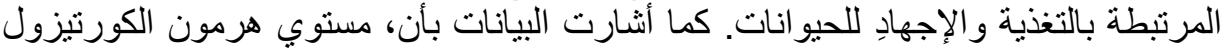

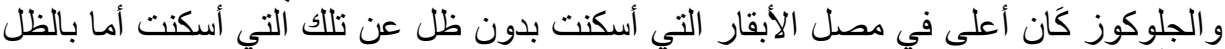
فقط أَو بالظل و المروان أعلى في 
Thirty mid-lactation Friesian cows, 178 day post-partum were randomly assigned to three equal groups ( $\mathrm{N}=10$ per group). All animals were blocked for age (6 year old), stage of milk yield and average body weight. The experiment was carried out during the months of July and August, 2007 in which the first group of the experimented- animal was left in loose box without shade and expressed to heat stress while the second group was left in shaded box (white galvanized metal roof, 4 meters above the ground and covered about $70 \%$ of the yard area). However the later group left in a box supported with shade plus fans (fans were installed regularly at height of 2.4 meters above the ground and spaced 1.5 meters along the manger shed). Our study revealed that provision of shade had no significant effect on temperature-humidity index (THI) while providing shade and fans had significantly lowered THI. At the same time the shade and fans had a significant effect on daily milk production but shade alone had no significant effect on milk yield. Milk yield was slightly increased with shade (insignificant) and tended to be greater for shaded and cooled cows (significant) as compare to non shaded animals. Also, this study indicated that, forage intake was significantly lower for the experimented cows that housed without shade than for those housed with shade and fans. Providing dairy cows with access to shade or to shade and fans during summer season was effective in reducing mean rectal temperature and respiratory rate. Moreover, this study revealed some statistically significant differences in certain behavioral patterns of cows that housed without shade under the prevalent hot weather and those housed either under shade only or under shade and fans $(\mathrm{p}<0.01)$. Moreover, leucocytic series of the experimented cows was not significantly affected by any of the studied housing conditions however cortisol and glucose levels were significantly higher $(\mathrm{p}<0.01)$ in the serum of the experimented cows that housed without shade than in those housed either with shade only or with shade and fans.

Key words: Healthy status, reproductive behavior, dairy cattle hot sumner, and behavior.

\section{INTRODUCTION}

When European breeds of farm animals are introduced to tropical and subtropical countries, they are forced with many problems relating to the hot climate, that induced conditions of heat stress which caused by combination of environmental factors such as air temperature, 
relative humidity, solar radiation and wind speed. A vast array of physiological, biochemical and behavioral changes were induced in such animals.

Heat stress depresses feed intake and milk production in lactating dairy cattle (Blackshaw and Blackshaw, 1994, Kadzere et al., 2002 and west, 2003). When cow exposed to hot ambient temperatures, their respiration rate and body temperature will increase (Spiers et al., 2004) so, they adjust their behavior in an attempt to maintain thermal balance (Bennett et al., 1985 and Blackshaw and Blackshaw 1994).

Relief from heat stress for dairy cattle can be achieved by reducing the heat exchange from environment to the cow, and/or from cow to environment. Heat stress abatement from dairy cattle begins with providing shade (Her et al., 1988 and Kendall et al., 2006). Fisher et al. (2002) reported that the use of shade was necessary for dairy cows when ambient temperature exceeded $25^{\circ} \mathrm{C}$ and was effective in reducing animal temperature. Moreover, a good air exchange was helpful in removing heat and reducing moisture, gas and pollutant levels. Forced air movement improved convective heat transfer and speeds evaporation of moisture from the skin (Dan McFarland, 2004). Several studies have shown that cooled cows had lower rectal temperature and respiratory rates than non-cooled ones (Armstrong et al., 1985; Armstrong et al., 1988; Armstrong et al., 1993 and Chen et al., 1993).

The main objective of this study was to clarify the effect of hotly summer in Assiut on health status, productivity and behavior of Friesian dairy cattle and the evaluation of traditional ways to relief

\section{MATERIALS and METHODS}

\section{Animals, feeding and management:}

The study was carried out during the months of July and August, 2007. Animals were housed in a milking house system at the south east of Assiut Governorate, Egypt. Each house consists of a closed house and open yard with average space allowance of $25 \mathrm{~m}^{2} /$ head. Animals are kept in open yards at daylight hours while they kept in the closed box during night.

Thirty Friesian cows of the same age (6 year old) at their midlactation period (178 day post-partum) were used in this investigation. Cows were randomly assigned to three groups $(\mathrm{N}=10$ per group) and each group was housed in a separate house.

The study period in this investigation was 60 days preceded by a 14-day preliminary period. First group of animals was housed in a loose 
box without shade under the prevalent hot environmental weather while the second group was housed in a box shaded with galvanized metal roof of 4 meters height and covered about $70 \%$ of the yard area. However, the third group was housed in a box supported with shade as previously mentioned plus fans (fan was installed regularly at height of 2.4 meters above the ground and spaced 1.5 meters along the manger shed with power consumption of $60 \pm 7$ watt and speed equals $1150 \pm 70 \mathrm{RPM}$ ).

A fixed amount of commercial concentrate mixture was fed to the animals in the milking parlour according to their average milk yield; however, barseem was ad libitum offered to the experimented cows in their loose boxes. Mineral salt rocks were hanged freely in front of the animals. Cows were allowed free access to the water troughs which placed on the ground of their boxes.

\section{Climatic conditions:}

Environmental temperature and relative humidity percentages were determined by using wall mount - thermo-hygrometer, which was hanged, above the level of the ground by about one meter inside the examined building.

Temperature humidity index: (THI) was calculated according to Ravagnolo et al. (2000) by equation of: THI= $1.8 \times$ Ta- $(1-\mathrm{RH}) \times$ (Ta14.3) +32 . Where Ta is the average ambient temperature in ${ }^{\circ} \mathrm{C}$ and $\mathrm{RH}$ is the average relative humidity as a fraction of unit.

\section{Forage intake, health state and milk production:}

1. To measure daily forage intake, the amounts of the feed offered and refusals from each animal were recorded daily throughout the period of the experiment. Refusals feed was removed and weighed daily just prior to the morning feeding according to Little et al. (1979).

2. Animals were milked twice daily at 6.30 a.m and 5.00 p.m. The milk yields for each animal were recorded daily and the average yield was calculated daily as well as a weekly composite sample from the two milking was analyzed for fat percentage using Gerber's methods (APHA, 1985).

3. Body temperature and respiratory rate were measured (according Blood and Henderson, 1974) just prior to each milking. Rectal temperature was measured by using medical thermometer and respiratory rate was measured by counting the flank movements of the individual cow and recorded as the number of inspirations per minute.

\section{Behavioral patterns:-}


Behavior of the experimented animals was recorded according to Marten and Bateson (1988) and Fordham et al. (1991) using direct observation and scan sampling method where the observer can observe the experimented cows without being seen by them. Behavior of the experimented cows was recorded for 6 hours / day for 4 days / week for two consecutive weeks for each experimental period as follows:-

- Two hours in the morning after supplying the animals with their morning feeding (8:00 to 10:00 a.m.).

- Two hours in the afternoon (12:00 to 2:00 p.m.).

- Two hours in the evening after supplying the animals with their evening feeding (5:00 to 7:00 p.m.).

Recorded behavior of the experimented cows was analyzed according to Marten and Bateson (1988); Abdel-Rahman (1999) and Kendall et al. (2006) as follows:-

1. Eating time / cow / recorded hour: - where the average time that each cow was spent on eating during each recorded hour was calculated.

2. Number of eating bouts / cow / recorded hour: - where the average number of eating bouts that each cow did during each recorded hour was calculated. Eating bout is defined as eating activity which starts by the time that the animal begin to move its jaw to eat and ends when it stop chewing and swallowing the very last bolus. According to the previously mentioned authors, eating bouts was not considered ended if they returned to eat again within one minute.

3. Number of drinking bouts / cow / recorded hour: - where the average number of drinking bouts that each cow did during each recorded hour was calculated. Drinking bout is defined as drinking activity which starts by the time that the animal dips its mouth into the water surface and ended by raising of its head.

4. Time spent on water trough / cow / bout.

5. Standing time without eating or drinking activities /cow / recorded hour: - where the average time that each cow spent on standing without eating or drinking activities during each recorded hour was calculated.

6. Lying time / cow / recorded hour: - where the average time that each cow spent on lying down and resting during each recorded hour was calculated.

7. Behaviors of stress and restlessness: - where some behavioral patterns of stress were recorded as follows: -

\section{Bellowing:-}


Bellowing was defined as a loud vocalization emitted by stressed cattle. Repeated vocalization by the same cow was considered as one act.

\section{Pawing:-}

Pawing was defined as rubbing the floor vigorously with the claws of the hind limbs of stressed cattle.

\section{Stamping or sniffing the ground.}

\section{Lip licking:-}

It is another indicator of stress that defined as repeated and rapid licking of the upper lip (muzzle).

\section{Blood parameters:-}

During the last two days of each study period, three blood samples, $5 \mathrm{ml}$ each were drawn from the jugular vein of each animal of randomly selected five cows. The first one was drawn into glass test tubes contain EDTA for leucocytic count according to Franke and Reitman (1963). The second blood sample was drawn into centrifuge tubes and centrifuged for 30 minutes at 3000 r.p.m and the obtained sera were assayed within three hours for their glucose concentration according to Tinder (1969). The third blood sample was drawn into centrifuge tubes and centrifuged for 30 minutes at 3000 r.p.m and the obtained sera were freezed at $-80{ }^{\circ} \mathrm{C}$ and kept for further analysis to determine their cortisol level using TDx FLx system according to Dandliker and Sassure (1973).

\section{Statistical analysis:-}

Statistical analysis of the collected data were carried out according to procedures of completely random design, SAS (1995)

\section{RESULTS}

Table 1: Effect of shade and cooling on average prevailing environmental condition.

\begin{tabular}{|l|c|c|c|}
\hline $\begin{array}{l}\text { Housing condition } \\
\text { Parameters }\end{array}$ & Without shade & With Shade & $\begin{array}{c}\text { With Shade } \\
\text { and Fans }\end{array}$ \\
\hline $\begin{array}{l}\text { Mean air } \\
\text { Temperature }\left({ }^{\circ} \mathrm{C}\right)\end{array}$ & $35.87 \pm 0.75^{\mathrm{a}}$ & $35.37 \pm 0.62^{\mathrm{a}}$ & $34.25 \pm 0.68^{\mathrm{a}}$ \\
\hline $\begin{array}{l}\text { Mean relative } \\
\text { Humidity (\%) }\end{array}$ & $43.00 \pm 2.36^{\mathrm{a}}$ & $40.75 \pm 1.75^{\mathrm{a}}$ & $35.50 \pm 1.47^{\mathrm{b}}$ \\
\hline Mean THI & $84.27 \pm 1.48^{\mathrm{a}}$ & $83.18 \pm 0.54^{\mathrm{a}}$ & $80.78 \pm 0.90^{\mathrm{b}}$ \\
\hline
\end{tabular}

Figures in the same raw with different superscripts differs significantly $(\mathrm{p}<0.01)$. 
Table 2: Effect of shade and cooling on voluntary forage intake and average milk production.

\begin{tabular}{|l|c|c|c|}
\hline $\begin{array}{l}\text { Housing condition } \\
\text { Parameters }\end{array}$ & Without shade & With Shade & $\begin{array}{c}\text { With Shade } \\
\text { and Fans }\end{array}$ \\
\hline $\begin{array}{l}\text { Average forage } \\
\text { Intake (Kg/head/day) }\end{array}$ & $9.23 \pm 1.05^{\mathrm{a}}$ & $10.65 \pm 0.98^{\mathrm{a}}$ & $13.63 \pm 0.78^{\mathrm{b}}$ \\
\hline $\begin{array}{l}\text { Mean milk yield } \\
(\mathrm{Kg} / \mathrm{head} / \text { day })\end{array}$ & $7.4 \pm 0.76^{\mathrm{a}}$ & $8.15 \pm 0.62^{\mathrm{a}}$ & $10.14 \pm 0.33^{\mathrm{b}}$ \\
\hline Mean milk fat\% & $3.33 \pm 0.85^{\mathrm{a}}$ & $3.46 \pm 0.09^{\mathrm{a}}$ & $3.48 \pm 0.76^{\mathrm{a}}$ \\
\hline
\end{tabular}

Figures in the same raw with different superscripts differs significantly $(\mathrm{p}<0.01)$.

Table 3: Effect of shading and cooling on physiological parameters of the animals

\begin{tabular}{|l|c|c|c|}
\hline $\begin{array}{l}\text { Housing condition } \\
\text { Parameters }\end{array}$ & Without shade & With Shade & $\begin{array}{c}\text { With Shade } \\
\text { and Fans }\end{array}$ \\
\hline Rectal temperature $\left({ }^{\circ} \mathrm{C}\right)$ & $39.8 \pm 0.2^{\mathrm{a}}$ & $38.9 \pm 0.1^{\mathrm{a}}$ & $38.6 \pm 0.1^{\mathrm{b}}$ \\
\hline Respiratory rate $(\operatorname{Insp} . / \mathrm{min})$ & $41 \pm 2^{\mathrm{a}}$ & $31 \pm 1^{\mathrm{a}}$ & $28 \pm 1^{\mathrm{b}}$ \\
\hline
\end{tabular}

Figures in the same raw with different superscripts differs significantly $(\mathrm{p}<0.01)$.

Table 4: Behavioral patterns of the animals under different conditions.

\begin{tabular}{|l|c|c|c|}
\hline $\begin{array}{l}\text { Housing condition } \\
\text { Behavior }\end{array}$ & Without shade & With shade & $\begin{array}{c}\text { With shade } \\
\text { and Fans }\end{array}$ \\
\hline $\begin{array}{l}\text { Eating time } \\
\text { (min. / hour) }\end{array}$ & $13 \pm 2^{\mathbf{a}}$ & $18 \pm 1^{\mathbf{a}}$ & $24 \pm 1^{\mathbf{b}}$ \\
\hline $\begin{array}{l}\text { Eating bouts } \\
\text { (No. / hour) }\end{array}$ & $3 \pm 1^{\mathbf{a}}$ & $4 \pm 1^{\mathbf{a}}$ & $7 \pm 1^{\mathbf{b}}$ \\
\hline $\begin{array}{l}\text { Drinking bouts } \\
\text { (No. / hour) }\end{array}$ & $6 \pm 1^{\mathbf{a}}$ & $3 \pm 1^{\mathbf{b}}$ & $3 \pm 1^{\mathbf{b}}$ \\
\hline $\begin{array}{l}\text { Drinking time } \\
\text { (Sec. / bout) }\end{array}$ & $14 \pm 3^{\mathbf{a}}$ & $12 \pm 1^{\mathbf{a}}$ & $13 \pm 1^{\mathbf{a}}$ \\
\hline $\begin{array}{l}\text { Standing without activities } \\
\text { (min. / hour) }\end{array}$ & $33 \pm 4^{\mathbf{a}}$ & $18 \pm 2^{\mathbf{b}}$ & $11 \pm 2^{\mathbf{b}}$ \\
\hline $\begin{array}{l}\text { Lying down } \\
\text { (min. / hour) }\end{array}$ & $12 \pm 2^{\mathbf{a}}$ & $23 \pm 1^{\mathbf{b}}$ & $24 \pm 1^{\mathbf{b}}$ \\
\hline $\begin{array}{l}\text { Bellowing } \\
\text { (\% of animals) }\end{array}$ & $40^{\mathbf{a}}$ & $0^{\mathbf{b}}$ & $0^{\mathbf{b}}$ \\
\hline $\begin{array}{l}\text { Pawing } \\
\text { (\% of animals) }\end{array}$ & $0^{\mathbf{a}}$ & $0^{\mathbf{a}}$ & $0^{\mathbf{a}}$ \\
\hline $\begin{array}{l}\text { Stamping or sniffing } \\
\text { (\% of animals) }\end{array}$ & $40^{\mathbf{a}}$ & $10^{\mathbf{b}}$ & $10^{\mathbf{b}}$ \\
\hline $\begin{array}{l}\text { Lip licking } \\
\text { (\% of animals) }\end{array}$ & $60^{\mathbf{a}}$ & $10^{\mathbf{b}}$ & $10^{\mathbf{b}}$ \\
\hline
\end{tabular}

Figures in the same raw with different superscripts differs significantly $(\mathrm{p}<0.01)$. 
Table 5: Differential leucocytic count $\left(10^{3} / \mu 1\right)$.

\begin{tabular}{|l|c|c|c|}
\hline $\begin{array}{c}\text { Housing condition } \\
\text { Item }\end{array}$ & Without shade & With shade & With shade and Fans \\
\hline Total WBCs & $12.62 \pm 0.12$ & $12.34 \pm 0.12$ & $12.42 \pm 0.12$ \\
\hline Neutrophils & $7.34 \pm 0.10$ & $7.26 \pm 0.10$ & $7.24 \pm 0.10$ \\
\hline Lymphocytes & $3.41 \pm 0.10$ & $3.32 \pm 0.10$ & $3.36 \pm 0.10$ \\
\hline Monocytes & $1.21 \pm 0.04$ & $1.17 \pm 0.04$ & $1.18 \pm 0.04$ \\
\hline Eosinophils & $0.47 \pm 0.03$ & $0.43 \pm 0.03$ & $0.45 \pm 0.03$ \\
\hline Basophils & $0.190 \pm 0.01$ & $0.160 \pm 0.01$ & $0.190 \pm 0.01$ \\
\hline
\end{tabular}

Table 6: Serum cortisol ( $\mu \mathrm{g} / \mathrm{L})$ and glucose $(\mathrm{Mmol} / \mathrm{L})$ concentrations.

\begin{tabular}{|l|c|c|c|}
\hline $\begin{array}{l}\text { Housing condition } \\
\text { Item }\end{array}$ & Without shade & With shade & $\begin{array}{c}\text { With shade } \\
\text { and Fans }\end{array}$ \\
\hline Cortisol & $1.22 \pm 0.02^{\mathbf{a}}$ & $0.87 \pm 0.02^{\mathbf{b}}$ & $0.82 \pm 0.02^{\mathbf{b}}$ \\
\hline Glucose & $7.31 \pm 0.10^{\mathbf{a}}$ & $5.62 \pm 0.20^{\mathbf{b}}$ & $5.71 \pm 0.20^{\mathbf{b}}$ \\
\hline
\end{tabular}

Figures in the same raw with different superscripts differs significant $(\mathrm{p}<0.01)$.

\section{DISCUSSION}

\section{Effectiveness of shade and cooling:}

Table (1) showed that the mean environmental air temperature $\left({ }^{\circ} \mathrm{C}\right)$, relative humidity $(\%)$ and calculated temperature-humidity index (THI) during the different experimental conditions were $35.87,43.00$ and 84.27 during housing without provision of shade, 35.37, 40.75and 83.13 during housing under shade, while it was $34.25,35.5$ and 80.78 during housing under shade and fans, respectively. The previously mentioned data, showed that temperature-humidity index was higher than temperature -humidity index above critical thresholds accounted for heat stress (72) as stated by Armstrong et al. (1988) during different housing condition, a finding which indicating the exposure of cows to heat stress during the summer season. Also, it could be noticed that provision of shade had no significant effect on THI while providing shade with fans had significantly lowered THI $(\mathrm{P}<0.01)$. This result may be attributed to the fact that provision of shade only protected the animal from direct solar radiation and not reduces prevailing temperature (Armstrong et al., 88 and Kendall et al., 2006).

\section{Forage intake and milk production:}

The data represented in Table (2) illustrated that, forage intake for cows that housed without shade was $9.23 \mathrm{~kg} / \mathrm{head} /$ day while it was $10.65 \mathrm{~kg} / \mathrm{head} /$ day for cows that housed with shade only and $13.63 \pm 0.78$ 
$\mathrm{kg} / \mathrm{head} / \mathrm{day}$ for cows that housed with shade and fans. These data indicated that, forage intake was significantly $(\mathrm{p}<0.01)$ lower for the experimented cows that housed either with or without shade as compared to those housed with shade and fans.

The reduction in voluntary forage intake and the subsequent declines in milk production are direct responses to heat stress in lactating dairy cows (Beede and Collier, 1986). The adverse effect on milk yield was most likely mediated through a reduction in forage intake. Beede and Collier (1986) reported that, if cows are fed diets that allow sorting during high environmental temperatures, they selectively will decrease forage intake relative to concentrates in an attempt to reduce body core temperature through reduced heat production. The gross efficiency of conversion of feed to milk was lower for heat stressed cows. This suggested that an adaptive mechanism must have occurred in the heat stressed cows, resulting in higher maintenance requirements and lower efficiency of energy use for milk production. This, combined with the decrease in forage intake, would explain the decreased milk yield for these cows.

Also, the data represented in Table (2), showed the effect of shade as well as shade and fans on the milk yield and milk fat $\%$. These data indicated that the shade plus fans had a significant effect $(\mathrm{p}<0.01)$ on daily milk production, however housing under shade or shade plus fans had no significant effect on milk fat $\%$. Milk yield was significantly increased $(\mathrm{p}<0.01)$ by shade and cooled cows $(10.14 \mathrm{~kg} / \mathrm{head} /$ day $)$ as compare to shade $(8.15 \mathrm{~kg} / \mathrm{head} /$ day $)$ or non shaded animals (7.4 $\mathrm{kg} / \mathrm{head} /$ day). However, the milk yield was relatively increases when cows were shaded and cooled in comparison cows in shade only. This finding was agreed with Tarazon- Herrera et al. (1999) and Kendall et al. (2006). In addition, our study showed a non significant effect of shade and cooling on milk fat $\%$ and this result coincided with TarazonHerrera et al. (1999) who reported that the milk fat\% not affected by using shade or cooling. Typically, milk production declines as THI increases (Spiers et al., 2004) and this influence is magnified by consecutive hot days (Davison et al., 1988). While shade and cooling does provide some cumulative production benefit where the cows may have a sufficient cooling period to consumed feed to prevent any further decline in milk production (Igno et al., 1992).

\section{Physiological paramaters:}

Providing dairy cows with access to shade or to shade and fans during summer season was effective in reducing mean rectal temperature 
and respiratory rate from $39.8^{\circ} \mathrm{C}$ and $41 \mathrm{No} . / \mathrm{min}$. in non-shaded cows to $38.9^{\circ} \mathrm{C}$ and $31 \mathrm{No} . / \mathrm{min}$ in shaded group and $38.6^{\circ} \mathrm{C}$ and $28 \mathrm{No} . / \mathrm{min}$. in shaded and cooled group, respectively. Several studies such as Roman ponce et al. (1977); Davison et al. (1988) and Muller et al. (1994b) have also found that average body temperature was lower in shaded lactating cows than in cows with no shade. Also, Roman ponce et al. (1977) and Davison et al. (1988) found a positive reducing effect in respiratory rate in shaded cows than non shaded one.

The present findings concerning the decrease of rectal temperature and respiratory rate in cooled and shaded cows was agreed with that recorded by Armstrong et al. (1985); Armstrong et al. (1988); Armstrong et al. (1993) and Chen et al. (1993). Rectal temperature is a sensitive indicator of thermal balance and may be used to assess the negative effects of hot environment on growth, lactation and reproduction of dairy cows (Johnson, 1985 and West, 1993). It has been shown that a rise of $1{ }^{\circ} \mathrm{C}$ or less in rectal temperature is enough to reduce intake and production in dairy cattle (Johnson et al., 1963).such decrease in rectal temperature and respiratory rate indicates a much stronger response to the environment for shaded and cooled cows. These results coincided with Muller et al. (1994b), who found that cows without access to shade had a higher rectal temperature than shaded cows and that non-shaded cows were more susceptible to increase in ambient temperature.

\section{Behavioral observations:-}

A comparative evaluation of the data represented in Table (4) revealed statistically significant differences in some behavioral aspects of cows that housed without shade under the prevalent hot weather and those housed, either under shade only or under shade and fans $(\mathrm{p}<0.01)$.

The behavioral data represented in Table (4) illustrated that, eating time (min./hour), eating bouts (No./hour), drinking bouts (No./hour), drinking time (sec./bout), standing time without activities (min./hour) and lying time (min./hour) for cows that housed without shade were $13,3,6,14,33$ and 12 respectively while it were $18,4,3,12$, 18, 23 for cows that housed with shade only and 24, 7, 3, 13, 11, 24 for cows that housed with shade and fans, respectively. These data indicated that, both eating time, eating bouts and lying time were significantly lower for the experimented cows that housed either without shade or with shade only than for those housed with shade and fans. However, drinking bouts and the time that the cows spent standing without activities were significantly higher for the experimented cows that 
housed without shade than for those housed either with shade only or with shade and fans, which were insignificantly different. Moreover, these data indicated that the time that the cows spent drinking was insignificantly affected by any of the studied housing conditions.

With regard to behavioral aspects of stress and restlessness, the data represented in Table (4) illustrated that, the incidences of bellowing, pawing, stamping or sniffing the ground and lip licking among cows that housed without shade were $40,0,40$ and $60 \%$, respectively while it were $0,0,10,10 \%$ for cows that housed with shade only and were 0,0 , $10,10 \%$ for cows that housed with shade and fans, respectively. These data indicated that, the incidences of bellowing, stamping or sniffing the ground and lip licking were significantly $(\mathrm{p}<0.01)$ higher among the experimented cows that housed without shade than those housed either with shade only or with shade and fans, which were insignificantly different. However, the incidence of pawing the ground was zero for all.

The finding of this study agreed with Parker (1980); Sainsbury (1988); Pfau et al. (1992) and Kendall et al. (2006) who indicated that, housing of cows without shade under the prevalent hot weather reflected with a prominent disturbances on their behavioral patterns, specially those mentioned before, and these disturbances can be assessed as signs of stress and should be included in the practical management and monitoring system of cows.

\section{Blood parameters:-}

The data represented in Table (5) showed the effect of the studied housing conditions on the differential leucocytic count of the experimented cows. These data showed that, the counts $\left(10^{3} / \mu 1\right)$ of total WBCs, neutrophils, lymphocytes, monocytes, eosinophils and basophils due to housing of the experimented cows without shade under the prevalent hot weather were $12.62,7.34,3.41,1.21,0.47$ and 0.190 respectively. However, it were $12.34,7.26,3.32,1.17,0.43,0.160$ and $12.42,7.24,3.36,1.18,0.45,0.190$ following housing the experimented cows under shade only and shad with fans respectively. This result indicated that, leucocytic series of the experimented cows was not significantly affected by any of the studied housing conditions.

At the same time, the data illustrated in Table (6) showed the effect of these studied conditions on the serum levels of cortisol and glucose of the experimented cows. Serum cortisol and glucose levels were $1.22,0.87,0.82 \mu \mathrm{g} / \mathrm{L}$ and $7.31,5.62,5.71 \mathrm{Mmol} / \mathrm{L}$ following housing of the experimented cows under the prevalent hot weather without shade, with shade, with shade $\&$ fans respectively. 
These data indicated that, both of cortisol and glucose levels were significantly higher $(\mathrm{p}<0.01)$ in the serum of the experimented cows that housed without shade than in the serum of those housed either with shade only or with shade and fans, which were insignificantly different. The significant increase in the blood cortisol level of the experimented cows that housed without shade indicating an occurrence of stress and may be related to an outpouring of ACTH which intern stimulates the adrenal cortex to increase its secretion of glucocorticoids including cortisol (McDonald, 1969; Burchfield et al., 1980 and Stephens, 1981). However, the increase in blood glucose level of the same cows may be related to the fact that glucocorticoids, including cortisol, act on the hepatocytes which induced to produce gluconeogenic enzymes which in turn increase the rate of gluconeogenesis and enhance the conversion of protein to glucose. Moreover, cortisol causes a moderate reduction in the rate of glucose utilization by the body cells, which leads to a rise in blood glucose level (Guyton and Hall, 1996).

\section{CONCLUSION}

In conclusion, housing of dairy cows without shade was found to have an adverse effect on health, productivity and behavior. The data suggested that shade and fans were not sufficient to completely eliminate heat stress in cows because maxima for THI measured under the shade and fans remained high enough to decrease milk yield. The significant decrease in respiratory rate and rectal temperature of cows showed a partial alleviation of heat stress resulted from shade and fan, the effect of which was confirmed by the increases milk production and reduced losses.

\section{REFERENCES}

Abdel-Rahman, M.A. (1999): Changes in behavioral pattern of sheep in relation to feeding of diverse forages. $\mathrm{PhD}$ thesis, Faculty of veterinary medicine, Assiut University.

APHA, (1985): Amiracan Public Health Association" Standard methods for examination dairy product' INC $15^{\text {th }}$ Ed., Washintgn D.C.

Armstrong, D.V.; DeNise, S.K.; Delfino, F.J.; Hayes, E.J.; Grundy, P.J.; Montgomery, S. and Corea, A. (1993): Comparing three lactating performance of Holstein cows in hot weather. J.D.Sci., 64: 844-849. 
Armstrong, D.V.; Wiersma, F.; Fuhramann, T.J.; Tappan, J.M. and Gramer, S.M. (1985): Effect of evaporating cooling under a corral shade on reproduction and milk production in a hot aride climate. J.D.Sci., 68(Suppl.1): 167(Abst.).

Armstrong, D.V.; Wise, M.E.; Torabi, M.T.; Wiersma, F.; Hunter, R. and Kopel, E. (1988): Effect of different cooling systems on milk production of late lactation Holstein cows during high ambient temperature. J.D.Sci., 71(Suppl.1): 212(Abst.).

Beede, D.K. and Collier, R.J. (1986): Potential nutritional strategies for intensiviely managed cattle during thermal stress. J. Anim. sci. 62: 543-554.

Bennett, I.L.; Finch, V.A. and Holmes, C.R. (1985): time spent in shade and its relationship with physiological factors of thermoregulation in three breeds of cattle. App. Anim.Behav.Sci.13, pp. 227-236.

Blackshaw, J.K. and Blackshaw, A.W. (1994): Heat stress in cattle and the effect of shade on production and behavior. Aust.J.Exp.Agric.34, pp.285-295.

Blood, D.C. and Henderson, J.A. (1974): Veterinary Medicine. $7^{\text {th }}$ Ed., Bailliere-Tindall- London.

Burchfield, S.R.; Wood, S.C. and Elich, M.S. (1980): Pituitary adrenocortical response to chronic intermittent stress. Physiol. And Behav., 24: 297-302.

Chen, K.H.; Huber, J.T.; Theurer, C.B.; Armstrong, D.V.; Wanderley, R.C.; Simas, J.M.; Chan, S.C. and Sullivan, J.L. (1993): Effect of protein quality and evaporating cooling on lactational performance of Holstein cows in hot weather. J.D.Sci., 76: 819-825.

Dan McFarland, F. (2004): Managing heat stress. The dairy focus, volume 5 Issue 3.

Dandliker, W.B. and Sassure, D.V. (1973): Review article: fluorescent polarization immunoassay. Theory and experimental method. Immunochemistry, 10: 219-227.

Davison, T.M.; Silver, B.A.; Lisle, A.T. and Orr, W.N. (1988): The influence of shade on milk production of Holstein-Friesian cows in a tropical upland environment. Aust. J. Exp. Agric. 28, pp. 149-154.

Fisher, A.D.; Roberts, N. and Matthews, L.R. (2002): Shade: its use by livestock and effectiveness at alleviating heat challenge. Report to MAF policy, June, 2002. 
Fordham, D.P.; Gahtani, S.A.; Durotoye, L.A. and Rodway, R.G. (1991): Changes in plasma cortisol and B-endorphin concentrations and behavior in sheep subjected to a change of environment. Anim. Prod., 42: 157-159.

Franke, S. and Reitman, S. (1963): Clinical laboratory methods and diagnosis. $6^{\text {th }}$ Ed., C.V. Mosby Company, USA.

Guyton, A. and Hall, J.E. (1996): Textbook of medical physiology. $9^{\text {th }}$ Ed., W.B. Saunders, Philadelphia, USA.

Her, E.; Wolfenson, D.; Flamenbaum, I.; Folman, Y.; Kaim, M. and Berman, A. (1988): Thermal, productive and reproductive responses of high yielding cows exposed to short-term cooling in summer. J.D.Sci., 71: 1085-1092.

Igno, M.O.; Bjotvedt, G. and Sanford-Crane, H.T. (1992): Environmrntal profile and critical temperature effects on milk production of Holstein cows in desere climate. Int. J. Biometeorl. 36, pp. 77-87.

Johnson, H.D. (1985): Physiological responses and productivity of cattle. In: Yousef M.K.(Ed.), stress physiology in livestock, Basic principles, Vol., 1, 4-19, CRC Press, Boca Raton, Florida, 1985, pp. 4-19.

Johnson, H.D.; Ragsdale, A.C.; Berry, I.L. and Shanklin, M.D. (1963): Temperature-humidity effects including influence of acclimation in fed and water consumption of Holstein cattle. Research Bulletin, No.63.

Kadzere, C.T.; Murphy, M.R.; Silanikove, N. amd Maltz, E. (2002): Heat stress in lactating dairy cows. A review, live-stock. Prod. Sci. 77 (2002), pp. 59.

Kendall, P.E.; Nielsen, P.P.; Webster, J.R.; Verkerk, G.A.; Littlejohn, R.P. and Matthews, L.R. (2006): The effect of providing shade to lactating dairy cows in temperate climate. Livestock Science, Vol. 103, issue 1-2, pp. 148-157.

Little, W.; Collis, K.A.; Gleed, P.T.; Sansom, P.F. and Allen, W.M. (1979): Effect of reduced water intake by lactating dairy cows on behavior, milk yield and blood composition. Vet. Rec., 106:547-551.

Marten, P. and Bateson, P. (1988): In Measuring behavior. Cambridge University Press, Cambridge, pp. 48-69.

McDonalds, L.E. (1969): Veterinary endocrinology and reproduction. $1^{\text {st }}$ Ed., Lea and Febiger, Philadelphia, USA. 
Muller, J.C.; Botha, J.A.; Coetzer, W.A. and Smith, W.A. (1994b): Effect of shade on various parameters of Friesian cows in Mediterranean climate in South Africa. 2. Physiological responses, South Afr. J. Anim. Sci. 24, pp. 50-60.

Parker, W.H. (1980): Health and disease in farm animals. $3^{\text {rd }}$ Ed., Oxford - London. UK.

Pfau, A.; Shebaita, M.K. and Yosri, R.M. (1992): Water economy and wayter pool in animals under heat stress. Int. J. Anim. Sci., 7 (2): $235-240$.

Ravagnolo, O; Mistztal, I. and Hoogenboom, G. (2000): Genetic component of heat stress in dairy cattle, development of heat index function. J.D.Sci., 83(2000), pp. 2120-2125.

Roman-Ponce, H.; Thatcher, W.W.; Buffington, D.E.; Wilcox, C.J. and Van Hom, H.H. (1977): Physiological and production responses of dairy cattle to a shade structure in a subtropical environment. J. D. Sci., 60, pp. 424-430.

Sainsbury, D. (1988): Livestock health and housing. $3^{\text {rd }}$ Ed., Bailliere Tindall, London, UK.

SAS (1995): Statistical analysis system. User's Guide: Statistics. Version $6,2^{\text {nd }}$ Ed., SAS Inst. Inc., Cary, NC.

Spiers, D.E.; Spain, J.N.; Sampson, J.D. and Rhoads, R.P. (2004): Use of physiological parameters topredict milk yield and feed intake in heat stressed dairy caws. J. them. Biol.29, pp. 759-764.

Stephens, D.B. (1981): Stress and its measurements in domestic animals. Adv. Vet. Comp. Msd., 24: 179-210.

Tarazon-Herrera, M.; Huber, J.T.; Santos, J.; Mena, H.; Nusso, L. and Nussio, C. (1999): Effects of bovine somatotropin and evaporative cooling plus shade on lactation performance of cows during summer heat stress. J.D.Sci., 82: 2352-2357.

Tinder, P. (1969): Determination of glucose in blood using glucose oxidase with an alternative oxygen acceptor. Annals. Clin. Biochem., 6: 24-27.

West, J.W. (1993): Nutritional strategies for managing cattle the heat stressed-dairy cow. J.Anim. Sci., 77 (suppl. 2): 21-35.

West, W. (2003): Effects of heat stress on production in dairy cattle. J.D.Sci. 86(2003), pp. 2131-2144. 